\title{
Evaluating The Integrated Environmental Management Of Munici- pal Solid Waste In Osaka City, Japan
}

\author{
Sintha Prima Widowati
}

Received: 29102014 / Accepted: 31102014 / Published online: 31122014

(c) 2014 Faculty of Geography UGM and The Indonesian Geographers Association

\begin{abstract}
Many state-of-the-art concepts and technologies on managing MSW have been developed for years. However, in Indonesia, the practice may still be insufficient because of the institutional capacity issue. This study aimed to evaluate the integrated environmental management for municipal solid waste in Osaka City, Japan. Method in use was descriptive analysis by literature review using official document "Environmental Management in Osaka City for Fiscal Year 1999" by Osaka City Environmental Bureau. Result showed Osaka City was adopting and modifying the Integrated Solid Waste Management (ISWM) suggested by Tchobanoglous et al. [1993] hierarchically using "Waste Reduction Principles" and establishing "Environmental Management Bureau" to handle the integrated solid waste management practice. More importantly, the implementation of ISWM was completely supported by the central government by law which was The Waste Disposal and Public Cleaning Law and by regulation which was the task distribution among central, prefectural and municipal government in managing the solid waste. These approaches were proven to be effectively implemented from top to bottom level thus should be recommended to the government of Indonesia.
\end{abstract}

Keywords: management, Municipal Solid Waste, environmental, institutional, Osaka city

\begin{abstract}
Abstrak Berbagai macam konsep dan teknologi dalam mengelola sampah kota telah banyak dikembangkan selama bertahun-tahun. Namun di Indonesia prakteknya masih belum sesuai karena permasalahan kapasitas kelembagaan. Penelitian ini bertujuan untuk mengevaluasi pengelolaan lingkungan terintegrasi untuk sampah di Kota Osaka, Jepang. Metode yang digunakan adalah analisis deskriptif dengan kajian pustaka menggunakan dokumen resmi "Environmental Management in Osaka City for Fiscal Year 1999” dari Osaka City Environmental Bureau. Hasil kajian menunjukkan bahwa Kota Osaka mengadopsi dan memodifikasi konsep "Integrated Solid Waste Management (ISWM)" milik Tchobanoglous [1993] secara hirarki menjadi prinsip-prinsip "Waste Reduction Principles" dan membentuk Osaka City Environmental Bureau untuk menangani implementasi ISWM. Implementasi tersebut sangat didukung oleh Pemerintah Pusat dengan penyusunan undang-undang, The Waste Disposal and Public Cleaning Law dan pembagian tugas pokok dalam pengelolaan sampah kota dari pusat, perfektur dan munisipal. Pendekatan-pendekatan tersebut terbukti dapat diimplementasikan secara efektif sehingga sebaiknya direkomendasikan kepada pemerintah Indonesia.
\end{abstract}

Kata kunci: pengelolaan, sampah kota, lingkungan, kelembagaan, kota Osaka

\section{Introduction}

Any use of resource on Earth will generate residues improper storage, collection and disposal practices. released into land, water bodies, and the atmosphere Moreover, the improper solid waste management which need to be purged in the end. Naturally, Earth practices have affected ecological imbalances which has the capacity to assimilate the residues so that they miserably disrupted the natural assimilative ability in will be wiped out effortlessly. However, in urban area, regard to disposal of waste [Tchobanoglous et al., 1993]. the enormous growth of population and the more Management problems of solid waste in urban area, hi-tech society nowadays have generated excessive well-known as Municipal Solid Waste (MSW), have accumulations of waste with major increase of solid been an urgent issue in Indonesia since 2000's. Although waste management problems. Since land resource is there have been many state-of-the-art concepts limited in urban area, accumulation of waste becomes and technologies on managing MSW, indication of an immediate consequence of life. This has led to more implementation may still be insufficient because of damaging effects to the environment and to human the institutional issue [Febrianie \& Sukarjaputra, health. According to the US Public Health Services 2004]. Moreover, the proper method was not likely there are 22 human diseases have had relationship with implemented in the final dumping site, due to financial and technical issue [Gunawan, 2005]. In the final dumping site, mostly wastes were just piled and piled email: sintha.widowati@upnyk.ac.id until they resembled a huge mountain of stinky, sticky 
and slurry repulsive mixed-wastes. In consequence, some undesirable unpleasant incidents might come up. One of such cases had occurred in TPA Bantar Gebang in Bogor which was the offsite Final Open Dumping Area for Jakarta Metropolitan City. After 15 years of operation, the people lived nearby had complaint about unpleasant odor during dry season, groundwater contaminated by heavy metal and bacteria which lead to various skin diseases, diarrhea, TBC, and Acute Upper Respiratory Infection [Anonim, 2003].

There is a critical demand for the government to pursue and develop the appropriate system in controlling the MSW management practice in Indonesia. Learning from the best in that particular matter can be one foremost method to do such a thing. One of many best practices in the world had been observed in Osaka City, Japan. The city had started to realized the importance of managing waste seriously in 1999 when the city generated about 1,79 million tons of waste in one year. Local government of Osaka City took the step to create some integrated environmental management programs to address the MSW issue of the city. Therefore, this study aimed to monitor and evaluate the integrated environmental management for municipal solid waste in Osaka City, Japan. Expectantly, the result of the study might bring deeper understandings for the government to develop the appropriate system for MSW management practice in Indonesia and for individuals to know what-to-do action in managing their solid waste on a daily basis.
Tchobanoglous et al. [1993] defined solid waste as varied mass of unwanted and/or useless throwaways from the urban community and the more akin accumulation of agricultural, industrial and mining wastes whereas municipal solid waste (MSW) was specified to include all the wastes generated in a community excluding waste from industrial process and agricultural activities. Meanwhile, the US EPA reports in 1999 considered MSW consist of wastes from residential, commercial, institutional, and some industrial sources [Franklin in Tchobanoglous \& Kreith, 2002].

Sources of MSW were recognized through its definition as follows: (1) residential, (2) commercial, (3) institutional [Tchobanoglous et al., 1993; US EPA, 1999]. Based on the nature of origin, MSW usually contained the organic and inorganic wastes. Organic wastes were mostly combustible and easy to naturally decompose (biodegradable) whereas inorganic wastes were noncombustible and non-biodegradable. The nature of origin of MSW materials was eminent factor to determine the treatments (e.g: storage, collection and disposal). Moreover, based on that quality, MSW materials were often able to be used again or even considered a resource for another item. To understand the MSW's nature of origin, Tchobanoglous et al. [1993] illustrated the flow of materials in urban setting to show where they were thrown and where they were likely to found in the time ahead (Figure 1).

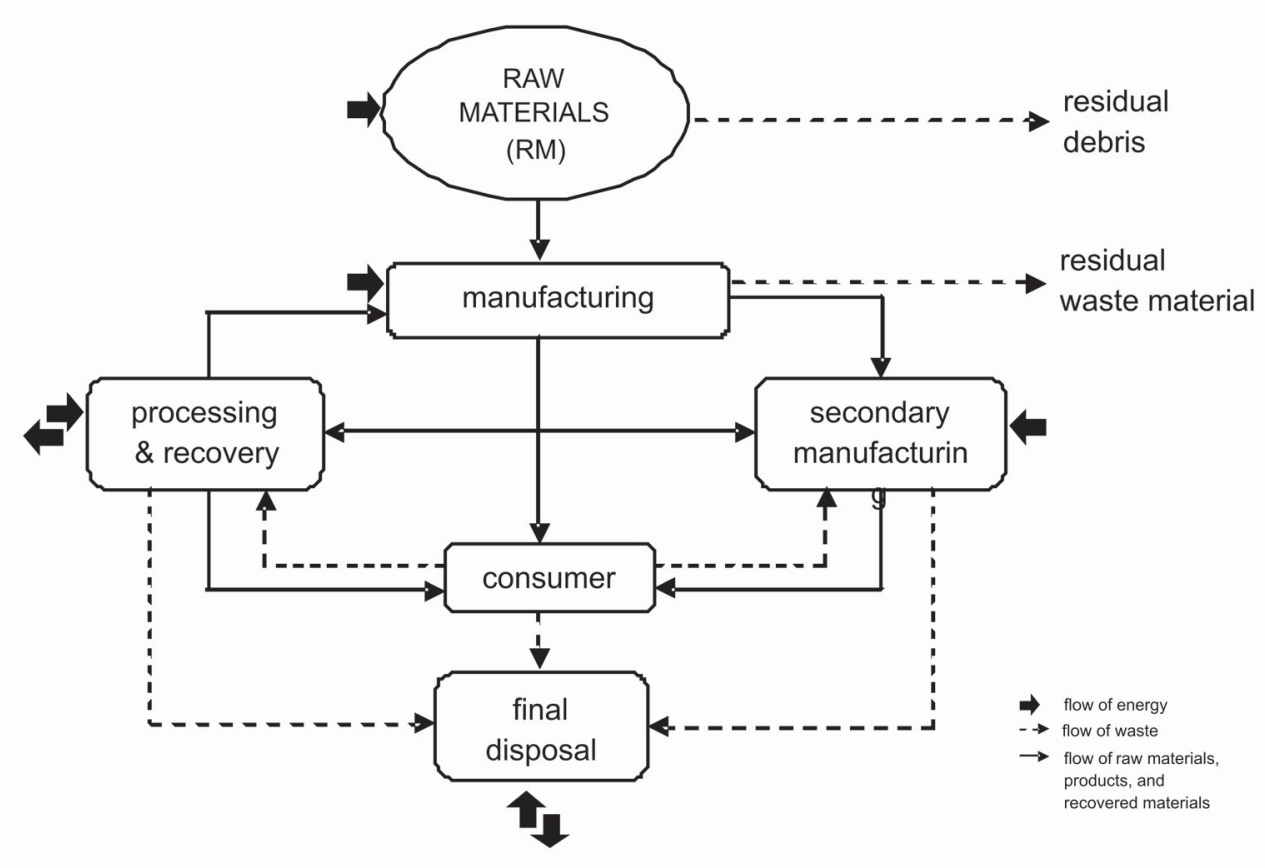

Figure 1. Diagram of Materials Flow and the Generation of Solid Waste in Urban Setting 
Solid waste management was described as controlling the generation, storage, collection, transfer and transport, processing and disposal of solid wastes in a proper method that is in harmony with the best principles of environmental considerations related to economics, engineering, public health, aesthetic, and conservation. Moreover, solid waste management should also be responsive to public opinions. Meanwhile, the definition of integrated municipal solid waste management (ISWM) was the selection and application of appropriate methods, technologies, and programs to achieve specified waste management objectives and goals [Tchobanoglous et al., 1993]. ISWM could be developed by evaluating all the six functional elements of municipal solid waste management system to identify the interfaces and connections among each element for effectiveness and efficiency in the waste management system.

The integrated solid waste management (ISWM) suggested by Tchobanoglous et al., [1993] consisted of four hierarchial elements which were:

1. Source Reduction

Source reduction involved reducing the quantity and/or toxicity of wastes generated at source. Reduction at source was the most effective way to minimize the wastes generation due to cost of handling, as well as impact to the environment and public health.

\section{Recycling}

Recycling involved activities such as: (1) separation and collection of waste materials based on the nature of origin; (2) preparation of the separated wastes components for reuse, reprocessing and remanufacture; (3) the action of reuse, reprocessing and remanufacture of the wastes. Recycling might help reduce the demand on new raw materials as well as the amount of wastes going to final disposal site.

\section{Waste Transformation}

Waste transformation involved activities which altered waste materials by physical, chemical and biological processed. These activities were implemented for some reasons such as: (1) improving the efficiency of SWM operations and systems; (2) recovering reusable and recyclable materials; (3) recovering conversion products (e.g.: compost) and energy (e.g.: heat and combustible biogas). Waste transformation was helping minimizing the volume of wastes going to final disposal site, thus prolonged the duration of landfills capacity.

\section{Landfilling}

Landfilling was the final step for (1) the solid wastes which could not be recycled and had no further use anymore; and (2) the residual entities of the separated waste at materials recovery facility and/or of the conversion products or energy. Up to present, there have been two alternatives in this last rank of ISWM hierarchy: (1) disposal on or in the earth's layer, or (2) disposal at the bottom of the ocean. In practice, landfilling was the least appropriate management method of solid wastes.

Even though the relationship amongst those four elements was hierarchical, Tchobanoglous \& Kreith [2002] found it might also be developed in interactive interrelationship among each element. In interactive option, the elements were interrelated to each other without any specific order. Both relationships were illustrated in Figure 2.

\section{The Methods}

The study was done using descriptive analysis. The methods used in this study was literature review using official document "Environmental Management in Osaka City for Fiscal Year 1999" by Osaka City Environmental Bureau to comprehend the Osaka City's integrated solid waste management system and to get more detailed information required.

\section{Result and Discussion}

Integrated solid waste management (ISWM) implemented in Osaka City was stemmed from the Japan's national waste management system which was developed based on Japan's national waste classification.

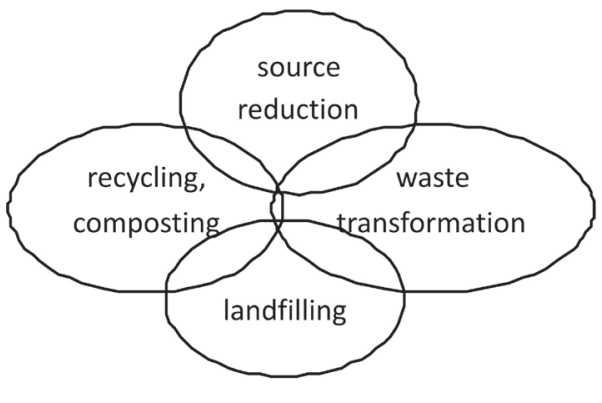

(a) interactive

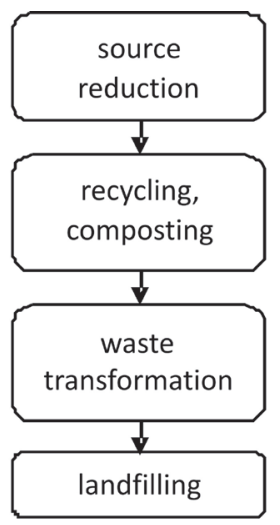

(b) hierarchical

Source: Tchobanoglous \& Kreith [2002]

Figure 2. Diagram of the Alternative Relationship among Elements of Integrated Solid Waste Managemen 
According to The Waste Disposal and Public Cleaning Law in Japan, all non-radioactive wastes were categorized into two types, Industrial and General. In accordance to the categorization, solid waste was regarded as General Waste. The detailed classification of non-radioactive wastes in Japan was shown in Figure 3.

Following up the national waste categorization, central government of Japan had set up the top-down waste management system for each waste category from national to municipality level. In national level, the central government had done several arrangements for both types of waste such as: (1) setting up the standardization of facilities, disposal and contract; (2) performing technical research and development on waste management; (3) facilitating public information and education about waste and waste management. In addition to that matter, national government was also undertaking technical advice, instruction, support, and supervision to prefectural government so that the prefectural government could develop the technical advice about disposal facilities and recommend the advice to: (1) municipalities for general waste; and (2) the companies that discharged industrial waste for industrial waste. Separately, for general waste, municipalities had similar duty with national government but implementation by municipalities should go closer to the residents. Moreover, municipalities were responsible to deal with private companies that handle the disposal of general waste. Meanwhile, industrial waste management was directly supervised by perfectural government. All companies with industrial waste were obligated to deal with any third party to handle the disposal matters. The flow of waste management in Japan was illustrated in Figure 4.

The Figure 4 showed solid waste was technically managed by municipality using standards set by the central government; as it was performed in Osaka City.

The matter of solid waste management in Osaka City was handled by Environmental Management Bureau. The bureau was divided into two main divisions, Services Division and Facilities Division. Those two divisions were then divided into smaller departments due to municipality's responsibilities stated in waste management system flow. The organizational chart of Osaka City's Environmental Management Bureau was illustrated in Figure 5.

The integrated environmental management for solid waste in Osaka City was mainly handled by Waste Reduction and City Beautification Department of Environmental Management Bureau. Under that department, ISWM implemented in the city using "Waste Reduction" guiding principle based on the hierarchical ISWM suggested by Tchobanoglous et al., [1993]. The principles of Waste Reduction were

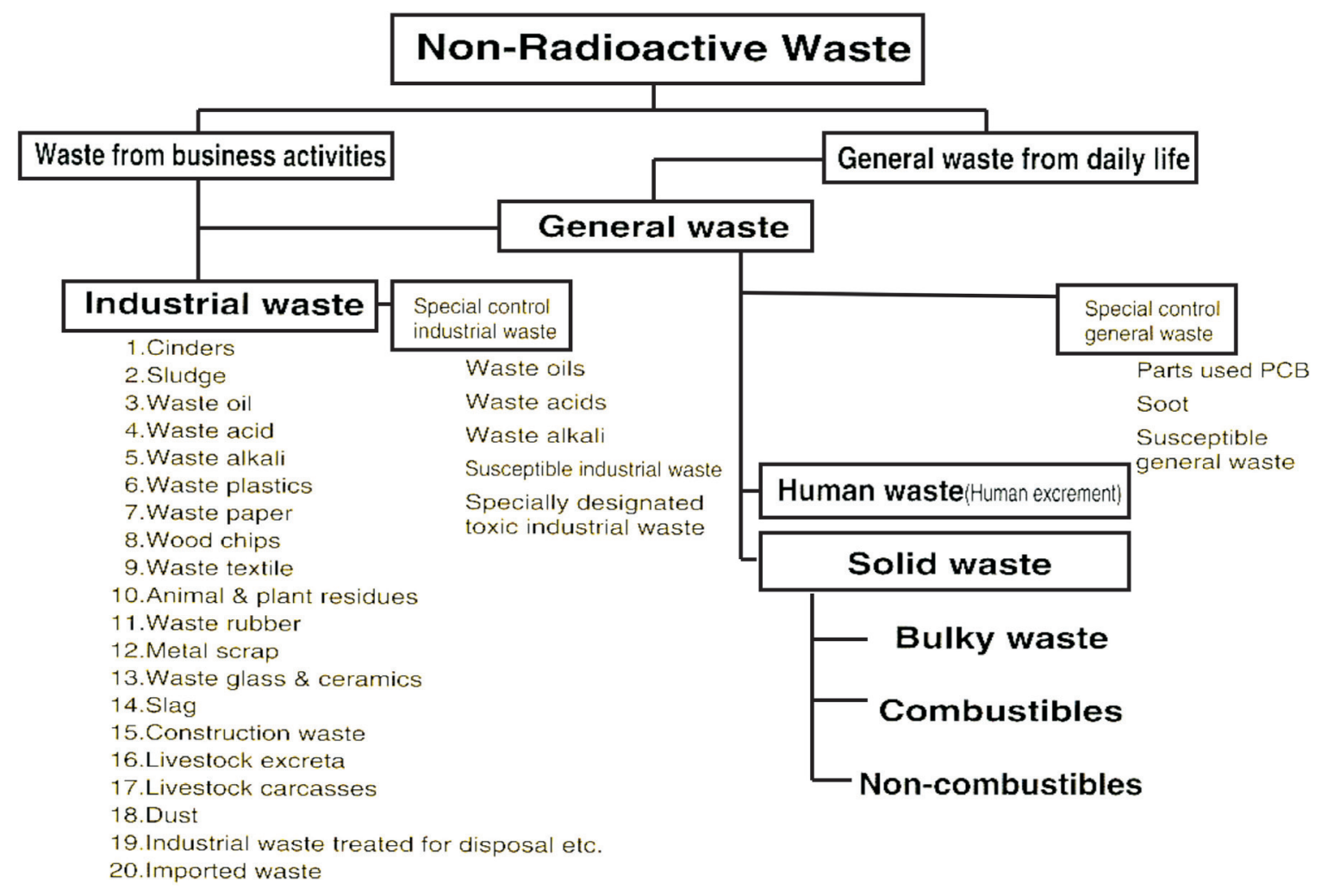

Source: Osaka City Environmental Management Bureau, 1999

Figure 3. Classification of Non-Radioactive Waste in Japan 
primarily set upon the notion of beautifying the city and lessening the adverse effect to the natural environment and human health, reinforced with a wide range of anti-pollution technologies and devices developed to prevent the release of detrimental substances (e.g.: leachate, dioxins).

1. There were four basic thoughts of Waste Reduction Principles such as follows: Minimizing waste generation which was described as to minimize the amount of waste generated in any activities at production, distribution and consumption stages of a

GENERAL WASTE

\begin{tabular}{|l|}
\hline NATIONAL GOVER NMENT \\
\hline Standarization of facilities, disposal, contract \\
Technical research and development Public \\
Information and education etc
\end{tabular}

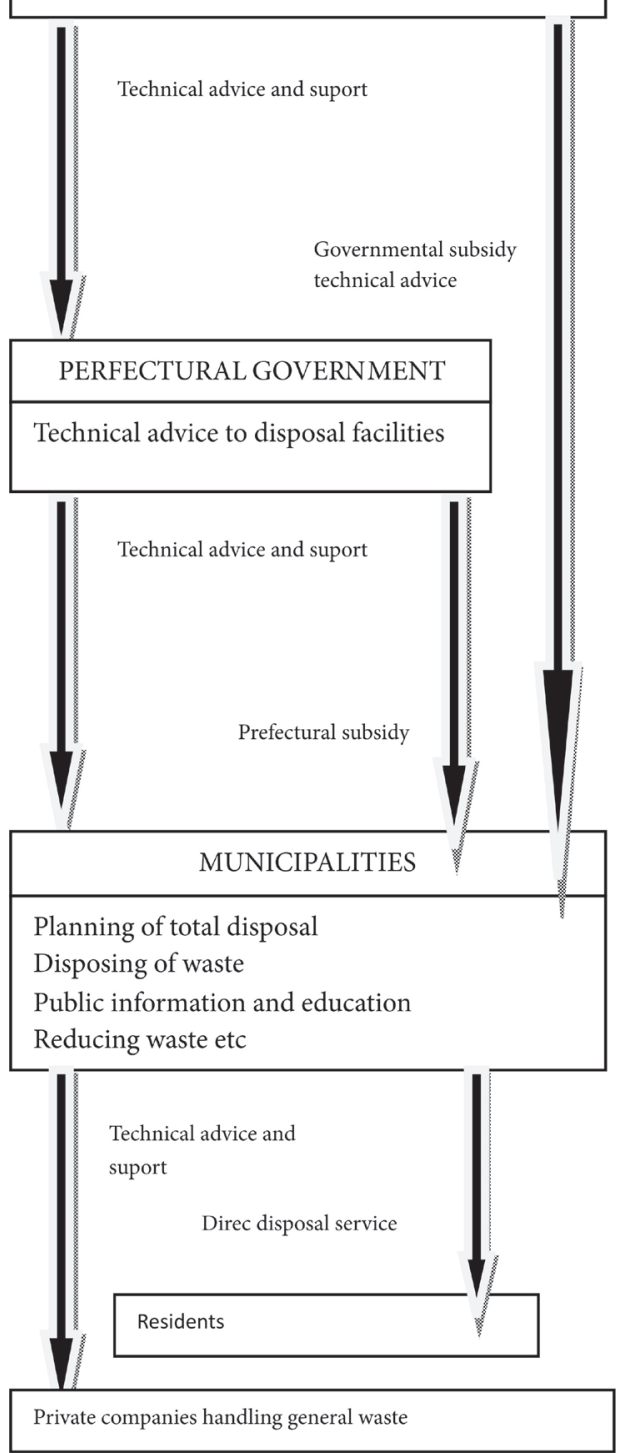

product.

2. Reusing which was described as to use over reusable items at many times as it is possible.

3. Recycling which was described as to promote product recycle when a product has gone beyond practical use or sentimental value.

4. Implementing appropriate treatment, which was described as to considerately handle and treat items which have been through the three preceding efforts and must be discharged as waste in such a proper manner so as to minimize the burden it puts on environment.

\section{INDUSTRIAL WASTE}

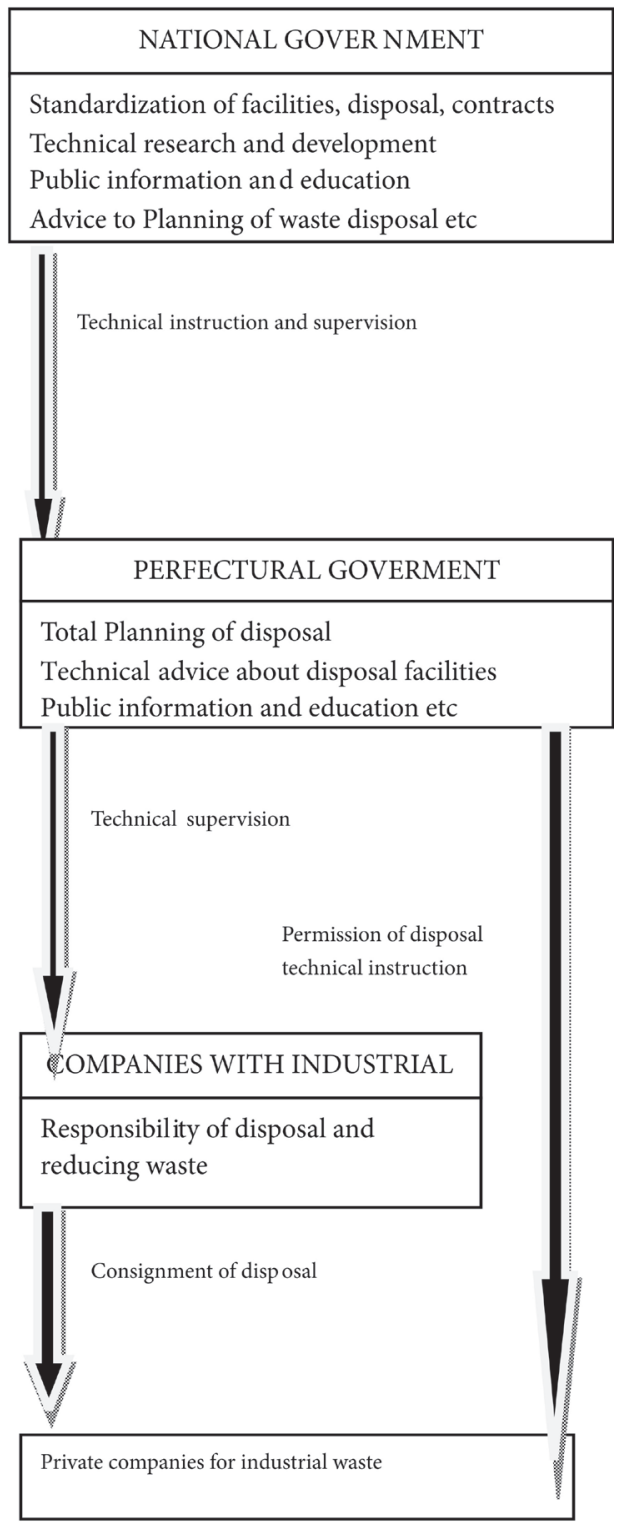

Source: Osaka City Environmental Management Bureau, 1999

Figure 4. Flow of Waste Management in Japan 


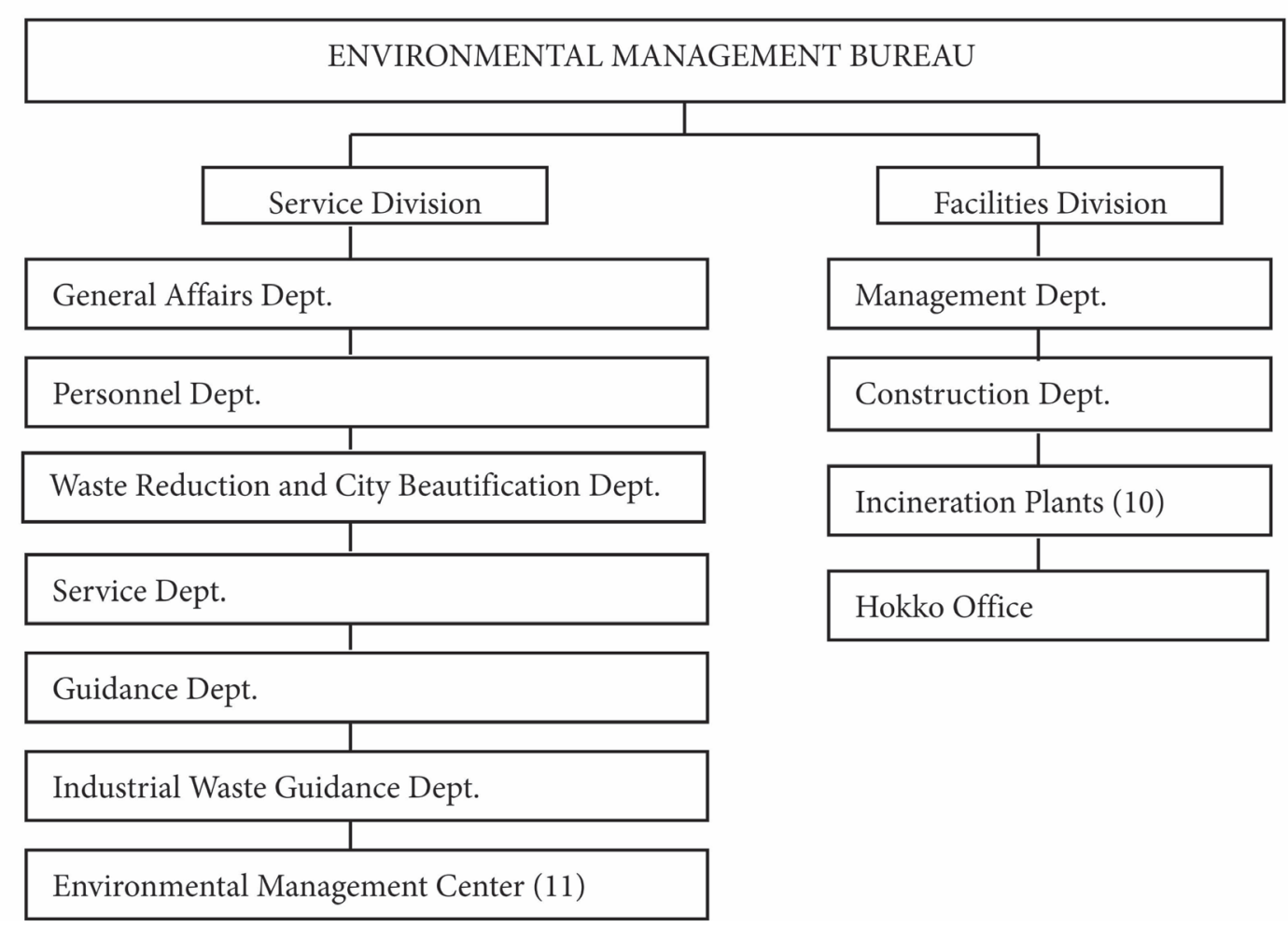

Source: Osaka City Environmental Management Bureau, 1999; modified

Figure 5. Organizational Chart Of Osaka City's Environmental Management Bureau

Table 1. Comparison between Tchobanoglous' hierarchy of ISWM and Osaka City's ISWM

\begin{tabular}{lll}
\hline No. & Tchobanoglous' hierarchy of ISWM & \multicolumn{1}{c}{ Osaka City's ISWM } \\
\hline 1. $\quad$ Source Reduction & $\begin{array}{l}\text { Minimizing waste generation which was described as to } \\
\text { minimize the amount of waste generated in any activities } \\
\text { at production, distribution and consumption stages of a } \\
\text { product. } \\
\text { Reusing which was described as to use over reusable } \\
\text { items at many times as it is possible. } \\
\text { Recycling which was described as to promote product } \\
\text { recycle when a product has gone beyond practical use or } \\
\text { sentimental value. }\end{array}$ \\
2. Recycling & $\begin{array}{l}\text { Implementing appropriate treatment, which was de- } \\
\text { scribed as to considerately handle and treat items which } \\
\text { have been through the three preceding efforts and must } \\
\text { be discharged as waste in such a proper manner so as to } \\
\text { minimize the burden it puts on environment. }\end{array}$ \\
& \\
&
\end{tabular}


In comparison with Tchobanoglous' hierarchical ISWM, the first phase "Source Reduction" was adopted and modified into the first two of Waste Reduction Principles which were Minimizing Waste Generation and Reusing. The second phase "Recycling" was adopted into the same thing for the third principle. At last, the third and fourth phase, "Waste Transformation" and "Landfilling", were adopted and modified into the last principle, Appropriate Treatment for final disposal. This was because in the final disposal, waste would be transformed by physical, chemical and biological processed as they were needed to be treated safely for the sake of human beings and the environment. The comparison between Tchobanoglous' hierarchy of ISWM and Osaka City's ISWM were shown in Table 1.

In practice, the Waste Reduction Principles were implemented with reusing and recycling started from production stage of a product to the next following stages due to the product's life cycle until the final treatment when a product became unrecycleable and/ or unusable material. In Production Stage, companies were needed also to manufacture their product in a way that minimized the waste later on when the product was distributed to public. In Distribution Stage, companies should consider about the minimum waste should be generated of the product packaging while it is in a carrier (e.g.: containers, ships, trucks, etc.). In Consumption Stage, consumers were strongly suggested to be a wise shopping person who knew when to reuse/recycle a product and when to buy a brand new product. The whole process was illustrated in Figure 6.

WASTE REDUCTION PRINCIPLE PROCES

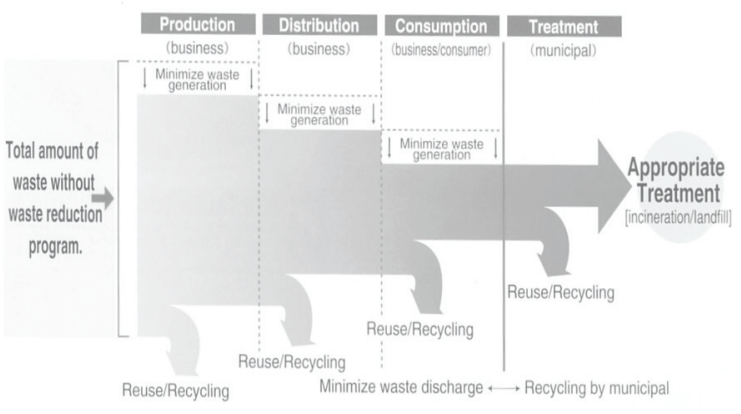

Source: Osaka City Environmental Management Bureau, 1999; modified

Figure 6. Waste Reduction Principle Process in Osaka City

Many awareness raising programs for general public and business were developed in Osaka City based on the Waste Reduction guiding principle so as citizens at all level could participate in reducing the waste generation such as:

1. Creating various educational posters and participating in community festival to promote city beautification and littering prevention.

2. Putting "No Litter Zone" signage and maps on street element in business and entertainment area to show the area where people were urged to keep the city clean.

3. Promoting the first day of each month as "Beutification Day", when the city called on communities and companies to clean up the streets in group and government employees were also called to clean the area around the public buildings.

Osaka City had also established Recycle Plaza to strengthen the citizens' awareness about waste as significant environmental problem thus some actions in waste reduction and recycling were inevitably needed to be done. In this plaza, citizens could get information regarding to recycling and put recycling into practice. Some activities in Recycle Plaza were: (1) Repairing furnitures and bicycles and giving them to those people who were willing to take good care of them; (2) Receive clothings and books that were no longer being used so that others could reuse them; (3) Offering Recycle-ItYourself classes such as papermaking and patchwork that used waste materials such as papers, old clothes and other materials to make such a beautiful artistic product; (4) Providing information on waste reduction and recycling in publication papers and videos.

Moreover, in order to promote Waste Reduction program, Osaka City has set up the Council to study a wide range of waste problems including how to minimize the amount of waste. The Council was also responsible to collect knowledge and opinions of academics, practitioners, common society, and business groups in regard to the waste issue.

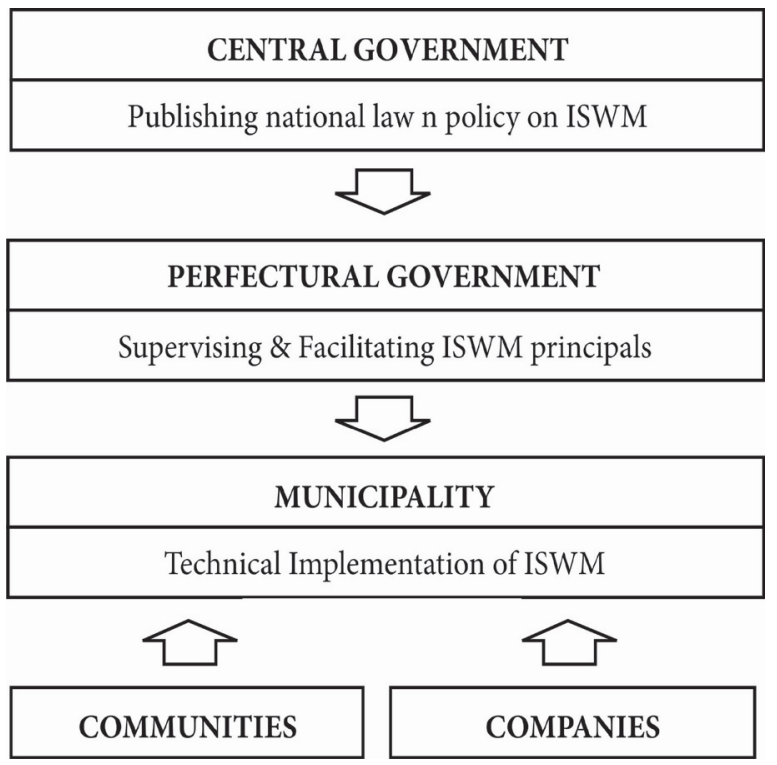

Source: Analysis result, 2014

Figure 7. Diagram of Institutional Instrument of ISWM in Osaka City 


\section{Conclusion}

Osaka City was adopting and modifying the Integrated Solid Waste Management (ISWM) suggested by Tchobanoglous et al.[1993] hierarchically using Waste Reduction Principles with four main steps which were: (1) Minimizing Waste Generation; (2) Reusing; (3) Recycling; (4) Appropriate Treatment. To handle the integrated solid waste management in practice, Osaka City was establishing "Osaka City Environmental Management Bureau". More importantly, the implementation of ISWM was completely supported by the central government by law which was The Waste Disposal and Public Cleaning Law and by regulation which was the task distribution among central, prefectural and municipal government in managing the solid waste. The availability of clear cut guidance and a strong will from the government at all level had made companies and citizens were actively and voluntarily taking part in the Waste Reduction Program of Osaka City. These approaches were proven to be effectively implemented from top to bottom level thus should be recommended to the government of Indonesia. In a

\section{References}

Anonim. (2003), Bantar Gebang dump area was closed, but problems still remaining (in $\mathrm{Ba}$ hasa), KOMPAS, http://www.kompas.com/ kompas\%2Dcetak/0307/25/metro/452185.htm.

Febrianie, S. \& Sukarjaputra, R. (2004), Waste and Government (in Bahasa), KOMPAS, http://www.kompas.com/kompas\%2Dcetak/0401/10/fokus/791775.

Gunawan, S.P.W. (2005), Waste recycle facilities and organic fertilizer production in Yogyakarta (in Bahasa), Undergraduate thesis, Universitas Gadjah Mada, Yogyakarta, Indonesia.

Osaka City Environmental Management Bureau (1999), Environmental Management in Osaka City: Maishima Incineration Plant. Environmental Management Bureau. Osaka. brief, the role of government from top to bottom level can be illustrated in Figure 7.

In order to be able to implement Integrated Solid Waste Management in Indonesia, this finding should be reflected into Indonesia's governance system. Indonesia had issued a National Law No. 32/2004 about Regional Autonomous Governance that allowed municipality to have self-governing system in their own region apart from the central government's and the provincial government's intervention. This was in accordance with the function of "technical implementation of ISWM" by Municipality of Osaka City. Moreover, in National Law No.25/2004 about National Development Planning System, the central government was obliged to publish national law, development plan and policy as well as program to be implemented in the lower level. Expectantly, with a clear cut guidance and a strong will from the government, citizens of Indonesia would actively and voluntarily take part in well-managing the municipal solid waste from waste generation to final disposal.

Tchobanoglous, G., Theisen, H., \& Vigil, S. (1993), Integrated Solid Waste Management: Engineering Principle and Management Issues, McGraw-Hill, Inc, USA.

Tchobanoglous, G. \& Kreith. (2002), Handbook of Solid Waste Management, Second Edition, McGraw-Hill Inc, USA.

U.S. EPA. (1999), Characterization of Municipal Solid Waste in the United States: 1998 Update EPA/530R-99-021, U.S. Environmental Protection Agency, Washington DC. 